\title{
Occurrence and Distribution of Chlorococcales in Konandur Pond of Thirthahalli Taluk, Karnataka
}

\author{
Nagaraj Parisara ${ }^{1}$, J.Narayana ${ }^{2}$, B.R.Kiran ${ }^{3}$ \\ ${ }^{1}$ Department of Environmental Science, Sahyadri Science College (Autonomous), Shivamogga, \\ Karnataka. \\ ${ }^{2}$ Department of P.G.Studies and Research in Environmental Science, Kuvempu University, \\ Shankaraghatta, Karnataka, India. \\ ${ }^{3}$ Research \& Teaching Assistant in Environmental Science, DDE, Kuvempu University, \\ Shankaraghatta, Karnataka, India.
}

\begin{abstract}
The present study deals with the occurrence and distribution of chlorococcales in relation to physico-chemical characteristics of Konandur pond in Thirthahalli taluk, Karnataka. A total of 15 species of Chlorococcales belonging to 9 genera were recorded of which Scenedesmus consists of 4 species followed by Ankistrodesmus, Selenastrum and Pediastrum with 2 species each respectively. The physico-chemical parameters were analyzed as per standard methods. The study revealed that, pond water was not polluted so much. According to the standard of water quality recommended by BIS, the pond water should be used for drinking and cooking after proper treatment.
\end{abstract}

Keywords: Chlorococcales, water quality, Konandur pond. Thirthahalli taluk

\section{INTRODUCTION}

The physical and chemical properties of fresh water bodies are characterized by the climatic, geochemical, geo-morphological and pollution conditions. The quality of aquatic life depends on the water quality. In order to utilize fresh water bodies successfully for all purposes, it is very important to study the physicochemical factors which influence the biological productivity of the water body.

Diversity measures are more useful in lake ecosystem, which harbor a large variety of algal species in general, and species diversity within genera. Therefore application of species richness indices is very essential. Secondly it is necessary to apply models that describe the distribution of species abundance. The diversity of a community may therefore be described by referring to the model, which provides the closest fit to the observed pattern of species abundance (Shankar Hosmani , 2010).

Chlorococcales is an order of green algae in the class Chlorophyceae. Individual specimens are sometimes found in soil, but mostly in fresh and marine waters. The order contains approximately 780 species ("Order: Chlorococcales Taxonomy Browser". Algae Base version 4.2, 2007).

The main objective of the present study is to know the distribution and abundance of chlorococcales in Konandur pond of Thirthahalli taluk in Shivamogga district.

\section{MATERIALS AND METHODS}

\subsection{Study Area}

Konandur pond is located in Theerthalli taluk of Shimoga district, Karnataka situated between $13^{\circ} 27^{\prime}$ and $14^{\circ} 39^{\prime}$ North latitude and between $74^{\circ} 38^{\prime}$ and $76^{\circ} 4^{\prime}$ East longitude. This water body is located at a distance of $80 \mathrm{~km}$ from Shivamogga town surrounded by agricultural fields which is utilized by the local people for drinking, irrigation, fishing, laundry etc.

\subsection{Water Quality Analysis}

Water was sampled on monthly basis, between 8 to 10 AM from June 2001 to May 2003. The water samples were collected in good quality polythene bottles. Water temperature was recorded at the sampling site itself by using mercury thermometer. Dissolved oxygen was fixed on the spot itself in 
BOD bottles. Remaining water quality parameters were estimated as per the standard methods (Trivedy and Goel, 1986; APHA, 1998).

\subsection{Estimation of Chlorococcales}

Chlorococcales were collected by using a plankton net made of bolting silk cloth of meshes of $10 \mu \mathrm{m}$ fixing a glass bottle of $100 \mathrm{ml}$ at a narrow end. For taking the samples of qualitative analysis, the net was towed for 5 minutes just below the surface of water (Green and Holden,1960). Tows were restricted to a small area around each sampling point. The samples were immediately transferred to other bottles and preserved by adding $4 \%$ formalin as per the practice of Welch (1948). The qualitative estimation was done by taking one $\mathrm{ml}$ of sample from the stock samples at each time and repeated 5 times. Uniform distribution was made by agitating the samples thoroughly. Qualitative identification of planktonic organisms was done with the help of monographs and plankton are identified up to species level (Adoni et al., 1985; Bharathi and Hegde, 1982; Hegde and Bharathi (1985).

\section{RESUlts AND DiscuSSION}

\subsection{Water Quality}

The water has undergone changes in its physico-chemical properties due to ecological degradation, overflowing of water from adjacent paddy fields and other human activities. In the present investigation, an attempt has been made to assess the suitability of water for human consumption and domestic purposes.

The mean and range of water quality of Konandur pond is depicted in Table 1 . The water temperature of the pond fluctuated between 26 and $35^{\circ} \mathrm{C}$. The $\mathrm{pH}$ of water was deviated between the circum neutral range (6.8-7.3). The turbidity was found in the range between 12 and 20.8 NTU. Conductivity fluctuated 46.2 and $72.12 \mu \mathrm{mhos} / \mathrm{cm}$. The dissolved oxygen was ranged from 3.52-6.88 mg/l. The free carbon dioxide was fluctuated between 7.8 and $12.4 \mathrm{mg} / 1$.BOD concentration was fluctuated between 0.68 to $1.62 \mathrm{mg} / \mathrm{l}$. The COD value fluctuated from $6.0-12.8 \mathrm{mg} / 1$. The total hardness of water was deviated between $16-28.6 \mathrm{mg} / \mathrm{l}$. Total alkalinity in this pond was between 38.66 and $49.6 \mathrm{mg} / \mathrm{l}$. The calcium and magnesium were between 6.4-9.96 mg/l and 1.2-3.2 mg/l respectively. The range of the sulphate was 3.6-9.3 mg/l. The chloride concentration deviated from 10 to $17.6 \mathrm{mg} / \mathrm{l}$. The ammonical nitrogen was between $0.6-2.1 \mathrm{mg} / \mathrm{l}$. The nitrate- nitrogen of the water was fluctuated from 0.12 to 1.5 $\mathrm{mg} / \mathrm{l}$. The concentration of the phosphate was fluctuated between 0.12 and $1.6 \mathrm{mg} / \mathrm{l}$. The total dissolved solids content was found between 48.0 and $64.2 \mathrm{mg} / \mathrm{l}$ (Table 1).

Table1. Physico-chemical characteristics of Konandur pond with Mean, Standard Error and Range (mg/l, except $\mathrm{pH}$ and temperature)

\begin{tabular}{|l|c|c|c|c|}
\hline \multirow{2}{*}{ Parameters } & \multicolumn{2}{c|}{ 2001-2002 } & \multicolumn{2}{c|}{ 2002-2003 } \\
\cline { 2 - 5 } & Mean \pm S.E. & Range & Mean \pm S.E. & Range \\
\hline Air temperature & $31.66 \pm 9.4$ & $27-35$ & $30.33 \pm 8.75$ & $28-36$ \\
\hline Water temperature & $28.5 \pm 8.22$ & $26-32$ & $28.16 \pm 8.13$ & $26-35$ \\
\hline $\mathrm{pH}$ & $7.05 \pm 2.04$ & $6.8-7.3$ & $7.11 \pm 2.05$ & $6.8-7.5$ \\
\hline Turbidity & $15.92 \pm 4.59$ & $12.2-20.2$ & $16.13 \pm 4.65$ & $12-20.8$ \\
\hline Conductivity & $59.72 \pm 17.24$ & $46.2-72.12$ & $62.53 \pm 18.05$ & $56.4-70.4$ \\
\hline Dissolved oxygen & $4.97 \pm 1.43$ & $3.82-6.88$ & $4.65 \pm 1.34$ & $3.52-5.98$ \\
\hline Free carbondioxide & $9.94 \pm 2.86$ & $8.82-12.4$ & $9.10 \pm 2.62$ & $7.8-10.2$ \\
\hline Biological oxygen demand & $1.23 \pm 0.36$ & $0.92-1.58$ & $1.27 \pm 0.36$ & $0.68-1.62$ \\
\hline Chemical oxygen demand & $9.5 \pm 2.74$ & $6.4-12.2$ & $9.54 \pm 2.75$ & $6-12.8$ \\
\hline Total hardness & $22.64 \pm 6.54$ & $16-28.6$ & $22.40 \pm 6.46$ & $16.4-26.5$ \\
\hline Total alkalinity & $43 \pm 12.41$ & $40.44-49.66$ & $42.02 \pm 12.13$ & $38.66-47.7$ \\
\hline Calcium & $7.75 \pm 2.23$ & $6.4-9.2$ & $8.31 \pm 2.39$ & $6.8-9.96$ \\
\hline Magnesium & $2.07 \pm 0.59$ & $1.2-2.84$ & $2.83 \pm 0.81$ & $2.2-3.2$ \\
\hline Sulphate & $6.68 \pm 1.93$ & $4.8-8.6$ & $6.40 \pm 1.84$ & $3.6-9.3$ \\
\hline Chloride & $13.26 \pm 3.82$ & $10.4-17.6$ & $12.40 \pm 3.58$ & $10-15.2$ \\
\hline Ammonical nitrogen & $1.4 \pm 0.41$ & $0.8-2.1$ & $1.02 \pm 0.29$ & $0.6-1.88$ \\
\hline Nitrate-Nitrogen & $0.75 \pm 0.21$ & $0.12-1.58$ & $0.87 \pm 0.25$ & $0.33-1.22$ \\
\hline Phosphate & $0.78 \pm 0.22$ & $0.12-0.98$ & $0.91 \pm 0.26$ & $0.36-1.6$ \\
\hline Total dissolved solids & $53.7 \pm 15.50$ & $48-64.2$ & $56.93 \pm 16.43$ & $52.2-62.4$ \\
\hline
\end{tabular}


The seasonal variation of the parameters was represented in Table 2. In this table the two years data was represented separately. Among air and water temperatures in 2001-02 slightly high temperature was found in Konandur pond (Table 2). The $\mathrm{pH}$ values showed no greater variations among the seasons as well among the years. A little variation among seasons and through out the study period as found in all the parameters. All other parameters exhibited no significant differences among the comparison of the values.

Table2. Seasonal variation of physico-chemical parameters of Konandur pond

\begin{tabular}{|l|c|c|c|c|c|c|}
\hline \multirow{2}{*}{ Parameters } & \multicolumn{3}{|c|}{$\mathbf{2 0 0 1 - 2 0 0 2}$} & \multicolumn{3}{c|}{ 2002-2003 } \\
\cline { 2 - 7 } & Monsoon & $\begin{array}{c}\text { Post- } \\
\text { monsoon }\end{array}$ & $\begin{array}{c}\text { Pre- } \\
\text { monsoon }\end{array}$ & Monsoon & $\begin{array}{c}\text { Post- } \\
\text { monsoon }\end{array}$ & $\begin{array}{c}\text { Pre- } \\
\text { monsoon }\end{array}$ \\
\hline Air temperature & 32.75 & 29.25 & 32.25 & 29.5 & 29.25 & 33.00 \\
\hline Water temperature & 29.0 & 27.00 & 30.25 & 27.5 & 26.75 & 29.5 \\
\hline pH & 7.175 & 7.05 & 7.05 & 7.15 & 7.15 & 7.00 \\
\hline Turbidity & 19.9 & 14.00 & 12.45 & 20.35 & 15.6 & 13.875 \\
\hline Conductivity & 64.615 & 53.2325 & 58.065 & 68.25 & 61.275 & 61.34 \\
\hline Dissolved oxygen & 4.735 & 5.97 & 4.03 & 4.63 & 5.3575 & 4.225 \\
\hline Free carbon dioxide & 11.9 & 9.19 & 8.3 & 9.65 & 9.355 & 8.725 \\
\hline Biological oxygen demand & 1.08 & 1.36 & 1.395 & 1.105 & 1.3225 & 1.3525 \\
\hline Chemical oxygen demand & 10.95 & 8.45 & 8.705 & 11.45 & 8.48 & 9.1 \\
\hline Total hardness & 26.695 & 23.05 & 18.85 & 24.675 & 23.7 & 18.2 \\
\hline Total alkalinity & 41.035 & 42.05 & 44.45 & 41.58 & 40.06 & 45.935 \\
\hline Calcium & 8.645 & 7.025 & 8.45 & 9.605 & 6.875 & 7.6 \\
\hline Magnesium & 2.41 & 1.57 & 2.675 & 2.9125 & 2.9275 & 2.24 \\
\hline Sulphate & 7.4 & 5.565 & 6.975 & 7.0125 & 5.225 & 7.1 \\
\hline Chloride & 11.75 & 14.00 & 13.15 & 13.555 & 10.5 & 14.05 \\
\hline Ammonical nitrogen & 1.925 & 1.0575 & 1.13 & 0.8875 & 1.02 & 1.29 \\
\hline Nitrate-Nitrogen & 0.1725 & 1.115 & 0.8925 & 0.825 & 0.9125 & 0.98 \\
\hline Phosphate & 0.535 & 0.87 & 0.7275 & 0.84 & 1.185 & 0.935 \\
\hline Total dissolved solids & 51.585 & 53.655 & 56.85 & 56.7 & 57.255 & 55.9 \\
\hline
\end{tabular}

\subsection{Distribution of Chlorococcales}

\subsubsection{Periodicity}

A total of 15 species of Chlorococcales belonging to 09 genera were recorded of which Scenedesmus consists of 4 species followed by Ankistrodesmus, Selenastrum and Pediastrum with 2 species each respectively (Table 3). Distribution and monthly occurrence of the Chlorococcales is presented in Table 3 and Figure 1. Table 4 represents the seasonal variation of the Chlorococcales in Konandur pond. In this water body, the density of the phytoplankton was observed highest in pre-monsoon season with $12595 \mathrm{o} / \mathrm{l}$ and lowest in monsoon season with $7839 \mathrm{o} / \mathrm{l}$ (Table 4).

\section{Chlorococcales}

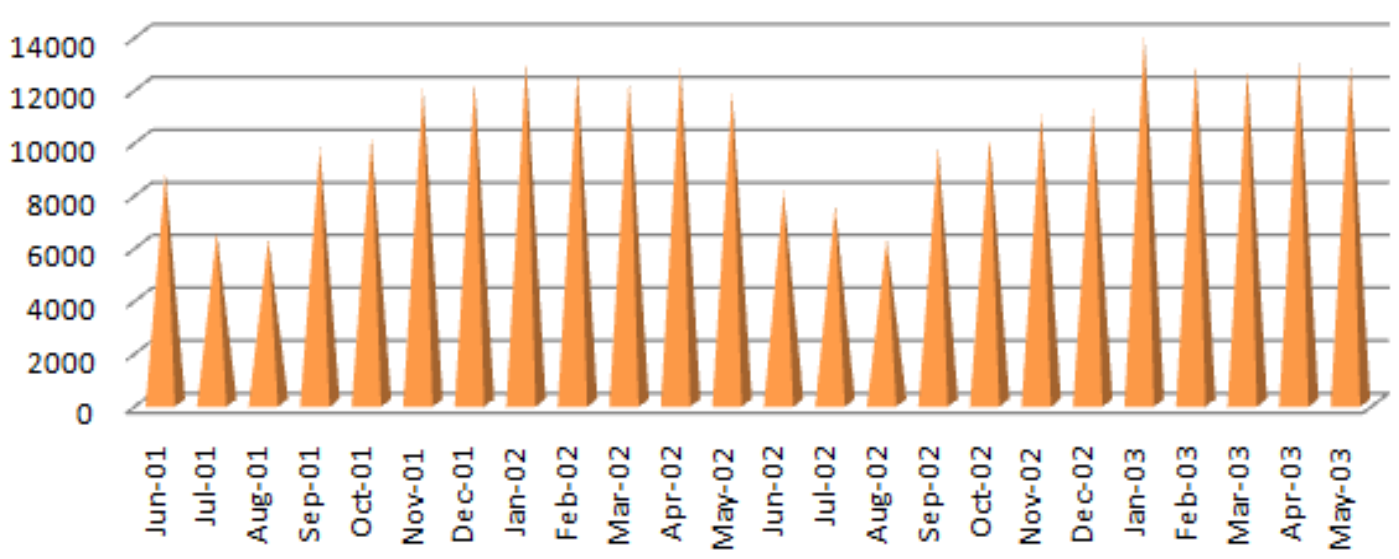

Figure1. Monthly variations of Chlorococcales in Konandur pond (org/l) 2001-2003 
Nagaraj Parisara et al.

Table3. Diversity of Chlorococcales in Konandur pond of Thirthahalli taluk during June 2001 to May 2003

\begin{tabular}{|c|c|c|c|c|}
\hline Sl.No & Name of the Organism & Site 1 & Site 2 & Site 3 \\
\hline 1 & Ankistrodesmus falcatus (Corda) Ralf) & + & - & + \\
\hline 2 & Ankstrodesmus spiralis (Turner) Lemn & + & + & + \\
\hline 3 & Closteriopsis longissima Lemm & + & + & - \\
\hline 4 & Crucigenia quadricauda & + & + & + \\
\hline 5 & Kirchneriella lunaris (Kirchner) Moeb & + & + & + \\
\hline 6 & Scenedesmus quadricauda Var. Maxima & + & + & + \\
\hline 7 & Scenedesmus dimorphous & - & + & + \\
\hline 8 & Scendesmus bijugatus & + & + & + \\
\hline 9 & Scendesmus accuminatus & - & + & + \\
\hline 10 & Selenastrum gracile & + & - & + \\
\hline 11 & Selenastrum westii & - & + & + \\
\hline 12 & Pediastrum simplex & + & + & - \\
\hline 13 & Pediastrum tetras & + & + & + \\
\hline 14 & Tetraedon minimum & - & + & + \\
\hline 15 & Coelastrum microporum & + & + & + \\
\hline
\end{tabular}

Table4. Seasonal variations (o/l) of Chlorococcales in Konandur pond

\begin{tabular}{|c|c|c|c|c|c|c|c|c|}
\hline \multicolumn{3}{|c|}{ 2001-2002 } & \multicolumn{3}{|c|}{ 2002-2003 } & \multicolumn{3}{c|}{ 2001-2003 } \\
\hline Monsoon & $\begin{array}{c}\text { Pre- } \\
\text { monsoon }\end{array}$ & $\begin{array}{c}\text { Post- } \\
\text { monsoon }\end{array}$ & Monsoon & $\begin{array}{c}\text { Pre- } \\
\text { monsoon }\end{array}$ & $\begin{array}{c}\text { Post- } \\
\text { monsoon }\end{array}$ & Monsoon & $\begin{array}{c}\text { Pre- } \\
\text { monsoon }\end{array}$ & $\begin{array}{c}\text { Post- } \\
\text { monsoon }\end{array}$ \\
\hline 7801 & 12345 & 11812 & 7876 & 12846 & 11562 & 7839 & 12595 & 11687 \\
\hline
\end{tabular}

Munawar (1970) and Seenayya (1971a) recorded the abundance of chlorococcales and attributed to phosphates and magnesium. While Hegde and Bharathi (1985) opined that chlorococcales prefer alkaline $\mathrm{p}^{\mathrm{H}}$.In the present investigation, higher temperature and higher dissolved oxygen appear to favour the rapid multiplication of chlorococcales. Their peaks were recorded in premonsoon season. Nevertheless, alkaline $\mathrm{p}^{\mathrm{H}}$ was seem to have a profound effect on multiplication of chlorococcales. Therefore, observations made in the present study are in conformity with the above researchers.

If the season wise distribution is accounted for, they were found to be higher during pre monsoon and decreased in their number towards monsoon season. A similar observation has been made by Shashikanth and Anand (1978).

Table 5 details the diversity indices calculated among the chlorococcales observed in the studied pond. All the sites possess almost all equal population density of chlorococcales. Thus, looking into these values, not much variation in the concentration of the physico-chemical parameters of the water depicts the availability of congenial habitat for the chlorococcales.

Table5. Diversity indices for Chlorococcales in Konandur pond

\begin{tabular}{|c|c|c|c|c|}
\hline Sites & $\mathbf{H}^{\mathbf{9}}$ & $\mathbf{J}$ & $\mathbf{D}$ & $\mathbf{E}$ \\
\hline Konandur & 2.18 & 0.805 & 8.4 & 0.56 \\
\hline
\end{tabular}

Where, $\mathrm{H}^{9}=$ Shannon-Weiner diversity index

$$
\begin{aligned}
& \mathrm{J}=\text { Shannon-Weiner equitability index } \\
& \mathrm{D}=\text { Simpson's diversity index } \\
& \mathrm{E}=\text { Simpson's equitability index }
\end{aligned}
$$

\section{Conclusion}

The water samples from Konandur pond was collected and analyzed for physico-chemical characteristics and chlorococcale composition. The ecological status of the pond was found to be impoverished in terms of species composition. A total of 15 species of Chlorococcales belonging to 09 genera were reported. As per BIS (1993) standards, the pond water should be used for human consumption and cooking after treatment. 


\section{REFERENCES}

Adoni, A.D., Gunwant Joshi, Kartik ghosh, Chourasia, S.K., Vaishya, A.K., Manoj Yadav and Verma, H.G. 1985. Work book on Limnology. Prathiba publishers, Sagar, India.

APHA.1998. Standard Methods for the Examination of Water and Waste Water, 20th ed. Public Health Association, Washington, D.C.

Bharati, S.G. and Hegde, G.R. 1982. Desmids from Karnataka State and Goa part III. Genus Cosmarium corda. Nova Hedwigia. Band XXXVI. Braunschweig : 733-757.

BIS: 3025. 1993. Methods of sampling and Test (Physical and Chemical) for water and waste water, Ist Revision, 1- 2.

Green, J. and Holden, M.J. 1960. The hydrology and plankton of the river Sokoto. J. Anim. Ecol., 29: 65-84.

Hegde, G.R. and Bharati, S.G. 1985. Comparative phytoplankton ecology of fresh water ponds and lakes of Dharwad, Karnataka state, India. Proc. Nat. Symp. Pure and Appl. Limnology. (Ed. Adoni, A.D.). Bull. Bot. Soc. Sagar. 32 : 24-39.

Munawar, M.1970. Limnological studies of fresh water ponds of Hyderabad, India. II.The BiocenoseDistributions of unicellular and colonial phytoplankton in polluted and unpolluted environments. Hydrobiologia 36: 105-128.

Munawar, M. 1970. Limnological studies on freshwater certain polluted and unpolluted environments. Hydrobiol., 39(1): 105-128.

Order: Chlorococcales Taxonomy Browser". AlgaeBase version 4.2. Retrieved 2007-09-22.

Seenayya, G. 1971a. Ecological studies on the phytoplankton of certain freshwater ponds of Hyderabad, India I. Physico-chemical complexes. Hydrobiologia $37: 7$-31.

Shankar P. Hosmani.2010. Phytoplankton diversity in lakes of Mysore district, Karnataka state, India. The Ecoscan 4 (1) : 53-57.

Shashikanth and Anand, V.K. 1978. Interrelationships of Phytoplankton and physical factors in Mansar lake Jammu (J \& K). Indian J. Ecol., 5(2) : 134 - 140.

Trivedi R.K. and Goel, P.K.1986. Chemical and biological methods for water pollution studies, Enviromedia, Karad,Maharastra, India.

Welch, P.S. 1948. Limnological methods, Balkistan Philadelphia, U.S.A: 281-381. 